\title{
Transformasi Kepemimpinan: Adaptasi Pesantren Bustanul Ulum Krai Lumajang dalam Menjawab Globalisasi
}

\author{
Ahmad Ihwanul Muttaqin 1*, Canda Ayu Pitara ${ }^{2}$ \\ ${ }^{1}$ Institut Agama Islam Syarifuddin Lumajang, Indonesia \\ 2 Institut Agama Islam Syarifuddin Lumajang, Indonesia
}

Keywords:

Transformasi Kepemimpinan, Pondok Pesantren, Globalisasi

*Correspondence Address: ihwan@iaisyarifuddin.ac.id
Abstract: This article aims to look at a crucial problem in Islamic boarding schools which is transformation of leadership. As it is known, the existence of boarding schools cannot be separated from Kiai as the founder, owner and caretaker of the boarding school itself. Such situation makes kiai has become a central figure within the process. Kiai appears to be charismatic figure and tends to be "authoritarian". However problems often arise in the process of succession in his leadership. The founding successors, most of the time, do not have the same charisma and influence as their predecessors. This situation made islamic boarding school experience a decline in the output quality and some of the islamic boarding schools went out of business. For this particular reason, the author would like to know how islamic boarding schools make changes in leadership patterns. The research locus took place at Bustanul Ulum islamic boarding school Krai Yosowilangun Lumajang. This particular islamic boarding school can be considered as a school that is able to adapt for changing times. The result of the research shown that in order to maintain the existence of islamic boarding school, the successors changed the pattern of leadership, from a single pattern to a collegial collective leadership and in the form of a foundation. As a result, the existence of islamic boarding school can be preserved, and to this day it has developed quite advanced.

\begin{abstract}
Abstrak: Artikel ini hendak melihat problem krusial di pondok pesantren yakni transformasi kepemimpinan. Seperti diketahui, keberadaan pesantren tidak bisa dipisahkan dari Kiai sebagai pendiri, pemilik dan pengasuh pondok pesantren. Kiai merupakan figur sentral di dalamnya. Kiai muncul sebagai sosok yang kharismatik dan cenderung "otoriter". Namun seringkali muncul problematika dalam proses suksesi kepemimpinannya. Kerapkali para penerus pendiri, tidak memiliki kharisma dan pengaruh yang sama dengan pendahulunya. Keadaan ini membuat pesantren mengalami penurunan kualitas output dan membuat sebagian pesantren gulung tikar. Atas dasar itulah, penulis ingin melihat bagaimana pesantren melakukan perubahan-perubahan pola kepemimpinan. Locus riset di Pondok Pesantren Bustanul Ulum Krai Yosowilangun Lumajang. Pesantren ini sejak berdiri hingga hari ini dapat disebut sebagai pesantren yang mampu beradaptasi dengan perubahan zaman. Dari hasil riset ditemukan bahwa untuk menjaga eksistensi pesantren, para penerus melakukan perubahan pola kepemimpinan, dari pola tunggal menjadi kepemimpinan kolektif kolegial dan berbentuk yayasan. Hasilnya, eksistensi pesantren dapat tetap terjaga, dan hingga hari ini pesantren mengalami perkembangan yang cukup maju.
\end{abstract}




\section{Pendahuluan}

Pesantren merupakan lembaga pendidikan tertua yang melekat dalam perjalanan kehidupan Indonesia sejak ratusan tahun silam. Ia adalah lembaga pendidikan yang dapat dikategorikan sebagai lembaga unik dan mempunyai karakteristik tersendiri yang khas, bahkan hingga saat ini ia mampu menunjukkan kapabilitasnya yang cemerlang dengan mampu melewati berbagai episode zaman serta melewati ragam polemik yang mengitarinya. Hal ini terjadi karena pesantren mampu melayani kebutuhan (needs) pendidikan masyarakat, terutama ketika lembagalembaga pendidikan modern yang pada umumnya bersifat formal, belum mampu menembus ke pelosok desa. Pada saat itu dunia pesantren menjadi simbol yang menghubungkan dunia pedesaan dengan dunia luar. ${ }^{1}$ Bahkan dalam perjalanan sejarahnya, pesantren telah banyak memberikan andil dan kontribusi yang sangat besar dalam ikut serta mencerdaskan kehidupan bangsa dan memberikan pencerahan terhadap masyarakat, serta dapat menghasilkan komunitas intelektual yang setaraf dengan sekolah gubernemen. Sehingga pada tataran ini pesantren tidak dapat diklaim sebagai institusi sosial yang tidak hanya berbentuk lembaga dengan seperangkat elemen pendukungnya seperti masjid, ruang mengaji, asrama santri, beberapa guru, dan kiai. Tetapi pesantren merupakan entitas budaya

1 In'am Sulaiman, Masa Depan Pesantren: Eksistensi Pesantren di Tengah Gelombang Modernisasi, (Malang: Madani, 2010), 3.

2 Hamdan Farchan dan Syarifuddin, Titik Tengkar Pesantren: Resolusi Konflik Masyarakat Pesantren, (Yogyakarta: Pilar Religia, 2005), 1.

${ }^{3}$ Yasmadi, Modernisasi Pesantren..,62.

4 Mujamil Qomar, Pesantren dari Transformasi Metodologi Menuju Demokrasi Institusi (Jakarta: Eirlangga, 2002), 1. yang mempunyai implikasi terhadap kehidupan sosial yang melingkupinya. ${ }^{2}$

Di Indonesia istilah pesantren lebih populer dengan sebutan pondok pesantren. Lain halnya dengan pesantren, pondok pesantren dari bahasa Arab funduq, yang berarti hotel, asrama, rumah dan tempat tinggal sederhana. Pengertian terminologi pesantren di atas, mengindikasikan bahwa secara kultural pesantren lahir dari budaya Indonesia. Dari sinilah Nurcholis Madjid berpendapat, secara historis pesantren tidak hanya mengandung makna keislaman, tetapi juga makna keaslian Indonesia. Sebab, memang cikal bakal lembaga pesantren sebenarnya sudah ada sejak lama. ${ }^{3}$

Pesantren juga sebagai lembaga yang mengiringi dakwah Islamiyah di Indonesia memiliki persepsi yang plural. ${ }^{4}$ Bahkan sejarah masuknya Islam di Indonesia yang prosesnya disebarkan dengan damai, salah satunya juga dengan cara membuat lembaga pendidikan pesantren. ${ }^{5}$ Pondok pesantren yang sering disingkat PPs ini merupakan lembaga pendidikan Islam yang lahir dan tumbuh dari kultur Indonesia yang bersifat indegenous. Ia tumbuh atas prakarsa dan dukungan masyarakat, serta didorong oleh permintaan dan kebutuhan masyarakat. ${ }^{6}$ Atas dasar itulah, saat krisis multi dimensional melanda elemen bangsa, dengan semakin merosotnya moralitas generasi mudanya akibat globalisasi, maka

5 Ahmad Ihwanul Muttaqin, "Dinamika Islam Moderat, Studi atas Peran LP. Ma'arif NU Lumajang dalam Mengatasi Gerakan Radikal," Tabiyatuna: Jurnal Pendidikan Islam. Vol. 12, No. 1 Februari 2019, 20.

${ }^{6}$ In'am Sulaiman, Masa Depan Pesantren (Malang : Madani, 2010), 1. 
perhatian para intelektual dan akademisi kembali melirik pesantren sebagai solusi pemecahannya. Belakangan, pesantren dicitrakan sebagai kunci dari penyelesaian krisis moral bangsa tapi kadang ditinggal setelah bangsa ini "sembuh." Nurcholis Madjid bahkan menyebut pesantren sebagai pendidikan alternatif.

Perubahan dan perkembangan zaman dengan berbagai variannya telah membawa implikasi terhadap pesantren. Para pengamat sosial mengidentifikasi perubahan-perubahan dengan membaginya menjadi beberapa komponen. Pertama, terjadinya teknologisasi. Kedua, perilaku yang semakin fungsional. Ketiga, penguasaan informasi dan teknologi. Keempat, kehidupan masyarakat yang makin sistemik dan terbuka. ${ }^{7}$ Komponenkomponen tersebut harus direspon pesantren. Pesantren diharapkan dapat memberikan reaksi atas tuntutan era global setidaknya dalam dua aspek, yakni universal dan nasional. Aspek universal yaitu ilmu pengetahuan dan teknologi, sedangkan dalam skala nasional adalah pembangunan di Indonesia. Untuk terakhir ini, peran pesantren harusnya semakin besar karena dituntut terlibat dalam pola pembangunan, sebagai perwakilan lembaga asli sesuai aspirasi bangsa Indonesia sendiri. ${ }^{8}$

Fenomena global memang tidak dapat dihindari, karena ia adalah kolonialisme dengan wajah baru yang merambah ke dalam berbagai sendi kehidupan manusia, terlebih dunia pendidikan. Nilai-nilai pendidikan secara umum dan khususnya pendidikan Islam hari ini semakin larut dalam gegap gempita berbagai

${ }^{7}$ Moch. Chotib, Pesantren dan Masyarakat Transformatif (Jember: Pena Salsabila, 2010), 21-22.

8 Yasmadi, Modernisasi Pesantren..,130. perubahan yang merupakan hasil dari pengaruh globalisasi. Tanpa terkecuali, realitas ini bahkan turut menjamah lembaga pendidikan pondok pesantren. Keadaan ini tidak dapat dihindari, mengingat pesantren pun adalah bagian dari masyarakat yang membutuhkan berbagai fasilitas untuk kemudahan dan efesiensi hidup, itulah sejatinya penawaran globalisasi itu.

Pendidikan Islam dan dakwah, khususnya pesantren sudah pasti bersentuhan dengan dinamika globalisasi tersebut. Disadari atau tidak, secara pasti globalisasi merupakan proses dan dinamika yang pengaruhnya telah berhasil mengebiri tradisi dan nilai-nilai luhur keagamaan umat Islam dewasa ini. Dinamika modernisasi serta globalisasi telah membawa dampak yang cukup serius dalam tatanan kehidupan umat beragama, khususnya bagi agama Islam. Sejatinya, globalisasi sudah menjadi keharusan sejarah yang banyak memberikan tantangan (threat) juga peluang (opportunity) dalam dunia pendidikan yang akan menggoyang tatanan kebudayaan, adat istiadat, dan nilai-nilai luhur ajaran Islam. Menyikapi alasan tersebut, maka pelu dikaji beberapa peluang juga tantangan yang ditimbulkan oleh globalisasi sehingga temuannya nanti menjadi seuntai masukan untuk menanggulangi pengaruhnya terhadap dunia pendidikan Islam. ${ }^{9}$

Ketika globalisasi telah jadi realitas keseharian yang harus dihadapi umat manusia termasuk pesantren dan masyarakat di negeri ini, pesantren harus mampu mencari solusi yang benar-benar mencerahkan sehingga pada satu sisi, dapat menumbuhkembangkan kaum santri

9 Suriana, "Pendidikan Islam Di Era Globalisasi : Menggapai Peluang Menuai Tantangan", Jurnal Mudarrisuna, Volume 4, Nomor 2, Juli - Desember, 2014,358-359. 
yang tidak gamang menghadapi modernitas dan sekaligus tidak kehilangan identitas dan jati dirinya. ${ }^{10}$ Pendidikan pesantren perlu berbenah dalam menghadapi tantangan zamannya antara lain soal keterlibatan dalam pembangunan nasional, kemajuan ilmu dan teknologi. ${ }^{11}$ Dari sekian banyak problem yang dihadapi pesantren, problem kepemimpinan menjadi yang paling krusial. Karena itulah, perlu dilakukan modernisasi dan transformasi dalam bidang kepemimpinan tersebut. Harus diakui, bahwa pola kepemimpinan di pesantren bersifat otoritas, pemegang keputusan sepenuhnya ada di tangan pimpinan pesantren. Bahkan Abdurrahman Wahid (Baca: Gus Dur) mengakui bahwa kepemimpinan di pesantren bersifat alamiah, karena pemimpin pesantren berikutnya tidak memiliki bentuk yang teratur dan tetap. ${ }^{12}$ Atas dasar itulah, Gus Dur menawarkan modernisasi kepemimpinan sebagai bentuk transformasi dan modernisasi dalam pendidikan Islam secara keseluruhan.

Berkenaan dengan itu pula, pesantren Bustanul Krai Yosowilangun Lumajang juga berupaya melakukan pengelolaan pondok pesantren dengan memperhatikan kecenderungan perubahan internal maupun eksternal. Semasa KH. Affan Abdul Malik pengasuh pertama pondok pesantren Bustanul Ulum, pesantren di pesisir pantai selatan ini menjadi magnet tersendiri bagi masyarakat di daerah Yosowilangun dan sekitarnya. Kharisma dan ketokohan pendiri dan pengasuh pesantren pertama menjadi embrio lahirnya masyarakat religius di sekitarnya. Tidak hanya karena

10 Abd A'la, Pembaruan Pesantren (Yogyakarta : Pustaka Pesantren, 2006), 6-8.

11 M. Ridwan Nasir, Format Pendidikan

Ideal (Pondok Pesantren Tengah Arus kedalaman spiritual, juga karena kecakapan keilmuan kiai yang mampu memberikan jawaban atas problem yang terjadi di masyarakat. Namun, pasca wafatnya pendiri pesantren, ada sistem yang berubah di internal pesantren terutama dalam aspek kepemimpinan. Tulisan ini hendak melihat pola dan model kepemimpinan yang berkembang pada periode kedua pesantren Bustanul Ulum Krai Yosowilangun Lumajang.

\section{Diskursus Kepemimpinan di Pondok Pesantren dan Globalisasi}

Diskursus mengenai kepemimpinan di pondok pesantren banyak ditulis oleh para peneliti, salah satunya Abdurrahman Wahid atau Gus Dur. Menurut Gus Dur, selain kepemimpinan di pesantren bersifat alamiah, ada keuntungan lain yang didapat jika pesantren tetap mengembangkan model kepemimpinan alamiah, namun Gus Dur tidak menampik jika terdapat pula kerugian yang muncul, misalnya penurunan kualitas kepemimpinan dengan berlangsungnya pergantian itu disebabkan tidak adanya bentuk dan aturan tetap.

Kerugian tersebut antara lain munculnya ketidakpastian perkembangan pesantren karena semua aspek akan bergantung pada keputusan pemimpinnya yang tentu akan berpengaruh pada penurunan kualitas output.

Selain itu, ada kekhawatiran akan terjadinya pembauran dalam tingkat kepemimpinan di tingkat lokal, regional dan bahkan nasional. ${ }^{13}$ Atas dasar itulah ia menawarkan konsep penataan sistem pesantren salah satunya dengan

Perubahan)(Yogyakarta : Pustaka Pelajar 2010),3.

12 Abdurrahman Wahid, Menggerakkan Tradisi (Yogyakarta: LKiS, 2011), 179.

${ }^{13}$ Wahid, Menggerakkan, 181-182 
menggabungkan pemikiran kultur tradisional Islam yang terbaik dengan mengadopsi hal baru yang tentu baik pula (al hifdzu ala al qadimis shalih wal alkhdu bil jadidi al ashlah). Oleh karena itu menurut Abdurrahman Wahid (Gus Dur) sudah seyogyanya semua unsur pemimpin di pesantren harus menguasai administrasi dan manajemen lembaga pendidikan, meski modelnya hanya pesantren. ${ }^{14}$

Senada dengan Gus Dur, Nurcholish Madjid merasa keberadan Kiai sebagai pimpinan pesantren ibarat jantung bagi kehidupan manusia. Hal ini terjadi karena kiailah perintis, pendiri, pengelola, pemimpin, pengasuh dan bahkan pemilik tunggalnya. Keadaan ini membuat beberapa pesantren bubar setelah ditinggal pengasuhnya. Sementara penerusnya tidak memiliki kapasitas yang sama dengan pendahulunya. Keadaan inilah yang lambat laun akan menimbulkan kesenjangan. Kerangka berpikir inilah yang memaksa pesantren melakukan transformasi dan perubahan krusial dalam menerapkan model kepemimpinannya. 15 Ia akhirnya menawarkan perubahan pola kepemimpinan dari perseorangan ke dalam bentuk yayasan.

Pada dasarnya peran kiai di pesantren terkait dengan tiga dimensi hubungan yakni hubungan kiai dengan santri, kiai dengan pesantren dan kiai dengan masyarakat. Ketiga hubungan tersebut akan harmonis jika kiai dapat menempatkan peran dan posisi secara tepat ditengah ketiga entitas tersebut. Tidak diragukan lagi bahwa peran kiai diterima oleh ketiga entitas bersumber dari keistimewaan (kharismatik) yang

\footnotetext{
${ }^{14}$ Abdurrahman Wahid, Nahdlatul Ulama dan Khittah (Yogyakarta: LKPSM, 1993), 161.

15 Lihat Nurcholish Madjid, Bilik-Bilik Pesantren, Sebuah Potret Perjalanan (Jakarta: Paramadina, 1992), 134-135
}

dimilikinya. Maka tidak heran jika kiai dapat berubah cepat memainkan perannya yakni selaku guru agama dan bapak (pengasuh) bagi santrinya, seorang pemimpin dan figur sentral di sebuah pesantren serta tokoh agama (ulama) dan tokoh sosial di tengahtengah masyarakat.

Kebesaran dan ketokohan seorang kiai karena berbagai faktor akan menjadi rentan oleh sebab timbulnya ketegangan dan konflik. Ketegangan dan konflik bisa bermuara pada perilaku personal dan juga sosial. Apabila seorang kiai tidak bisa mengatasinya dengan baik, maka konflik itu pada akhirnya akan berdampak pada perubahan posisi dan peran seorang kiai yang secara langsung atau tidak langsung juga berdampak pada jati diri seorang kiai itu sendiri, bagi santri, pesantren dan masyarakat yang menjadi bagian dari tanggungjawabnya.

Mengenai Globalisasi, banyak pakar memberikan definisi dari sudut pandang berbeda. Ada yang menyebut, globalisasi berasal dari Timur Tengah sejak peradaban Islam berkembang ke seluruh penjuru dunia. Ada juga yang berpendapat bahwa globalisasi bersumber dari Barat yang berhubungan dengan sistem ekonomi, politik, sains dan teknologi. Tetapi pada prinsipnya, globalisasi dapat dilihat dari beberapa aspek. Pertama, penyatuan umat manusia yang melampaui batas negara, bangsa, suku, ras dan agama. Kedua, asimilasi dan akulturasi budaya yang mengubah struktur kebudayaan setempat. ${ }^{16}$

Globalisasi adalah sebuah istilah yang memiliki hubungan dengan peningkatan keterkaitan dan

16 Abd. Rachman Assegaf, ed. Imam Machali, Presma UIN Kalijaga, Pendidikan Islam \& Tantangan Globalisasi: buah pikiran seputar filsafat, politik, ekonomi, sosial dan budaya, (Yogyakarta:Ar-Ruzz, 2004), 12. 
ketergantungan antarbangsa dan antarmanusia di seluruh dunia dunia melalui perdagangan, investasi, perjalanan, budaya populer, dan bentuk-bentuk interaksi yang lain sehingga batas-batas suatu negara menjadi bias.

Dalam banyak hal, globalisasi mempunyai banyak karakteristik yang sama dengan internasionalisasi, dan istilah ini sering dipertukarkan. Sebagian pihak sering menggunakan istilah globalisasi yang dikaitkan dengan berkurangnya peran negara atau batas-batas negara.

Globalisasi secara umum telah mengalami beragam fase. Menurut Kepala Pusat Kajian Center Of National Research Scientific (CNRS) Diminique Wolton, dunia masuki perkembangan baru globalisasi berupa globalisasi budaya, seperti k-pop dan lain semacamnya. Fase sebelumnya telah terjadi globalisasi massif di bidang politik terutama bidang ekonomi yang dimulai sejak kurun waktu tahun 1970an dan masih sangat terasa hingga saat ini sehingga membuka jurang yang lebar antara negara-negara maju dan berkembang.

\section{Metode}

Penelitian ini dirancang dengan metode kualitatif, yang bersifat deskriptive dan explorative, dalam arti penelitian ini termasuk penelitian lapangan dengan latar alamiah, ${ }^{17}$ peneliti sendiri yang mencari makna, ${ }^{18}$ dan lebih menekankan pada proses dari pada produk. ${ }^{19}$ Jenis penelitian ini

$\begin{gathered}17 \quad \text { Nasution, } \\ \text { Metode Penelitian } \\ \text { 2003), } 18 \\ \text { 18 Noeng Muhadjir, Metodologi Penelitian } \\ \text { (Bandung: Tarsito, }\end{gathered}$
Kualitatif, (Yogyakarta: Rake Sarasin, 1993), 8
19 Robert C. Bogdan and Sari Knopp
Biklen, Qualitative Research for Education: An
Introduction to Theory and Methods (London:
Allyn and Bacon Inc, 1992), 29-32

menggunakan studi kasus, yang sasarannya berupa manusia, peristiwa, latar dan dokumen, kemudian sasaran tersebut ditelaah secara mendalam sebagai suatu totalitas, sesuai dengan latar atau konteksnya masing-masing dengan maksud untuk memahami berbagai kaitan yang ada di antara variabel-variabelnya. ${ }^{20}$

Lokasi penelitian ini dilaksanakan di Pondok Pesantren Bustanul Ulum Krai Yosowilangun Lumajang. Subyek penelitian ini yaitu pengasuh atau kiai sebagai informan kunci, kemudian berlanjut pada informan lain, diantaranya: Majelis Keluarga, Pengurus Pesantren, Ustadz, Wali Santri, dan santri. Untuk penentuan informan yang dipilih dengan teknik purposive. Pengumpulan data dilakukan dengan menggunakan teknik wawancara mendalam, observasi, dan studi dokumenter. Sedangkan prosedur analisis data melalui beberapa tahapan yaitu: Data Condensation, Data Display, dan Conclusion Drawing/Verifications. ${ }^{21}$

Keabsahan data penelitian ini menggunakan triangulasi. Triangulasi ini peneliti lakukan dengan maksud untuk mengecek kebenaran data tertentu dan membandingkannya dengan data yang diperoleh dari sumber lain, pada berbagai fase penelitian lapangan pada waktu yang berlainan triangulasi akan dilakukan dengan dua cara yaitu dengan sumber data dan triangulasi metode. Triangulasi dengan sumber, dengan menggunakan cara: (1) membandingkan data hasil

20 Robert K. Yin, Studi Kasus Desain dan Methode, (Jakarta: PT. Raja Grafindo Persada, 2002), 18; Imron Arifin, Penelitian Kualitatif dalam Ilmu-Ilmu Social dan Keagamaan (Malang: Kalimasahada Press, 1996), 57

${ }^{21}$ Metthew B. Miles, A. Michael Huberman and Johnny Saldana, Qualitative Data Analysis, $A$ Methods Sourcebook, (Sage Publications, Inc., 2014), 31-33 
pengamatan dengan hasil wawancara; (2) membandingkan apa yang dikatakan orang di depan umum dengan yang dikatakan secara pribadi; Membandingkan apa yang orang-orang tentang situasi penelitian dengan apa yang dikatakan sepanjang waktu; (4) membandingkan keadaan dengan perspektif seseorang dengan berbagai pendapat dan pandangan orang lain seperti orang biasa, akademisi, praktisi politik, dan orang pemerintahan; (5) membandingkan hasil wawancara dengan dokumen yang berkaitan. Sedangkan triangulasi dengan metode, dengan menggunakan cara: pengecekan derajat kepercayaan penemuan hasil penelitian dengan menggunakan beberapa teknik pengumpulan data; (2) Pengecekan beberapa sumber data dengan metode yang sama.

\section{Hasil Penelitian dan pembahasan}

\section{Sejarah Pondok Pesantren Bustanul Ulum}

Sekitar tahun 1980-an, KH. Affan Abd. Malik memiliki keinginan untuk berhijrah dan membangun pesantren di luar Mlokerejo. Kemudian KH. Affan Abd. Malik kurang berkenan dengan beberapa tanah tersebut. Hingga pada suatu rutinan Malam Ju,'at manis di PP. Bustanul Ulum Krai Mlokerejo dan menuturkan keinginan beliau untuk berhijrah dan mencari tanah untuk dibangun pesantren. Kemudian Kiai Ahmad Tajuddin (Alumni Mlokerejo) mulai bermusyawarah perihal keinginan KH. Affan tersebut dengan KH. Hamid (salah satu tokoh masyarakat di tanah Krai).

Beberapa hari setelah musyawarah tersebut, KH. Hamid mulai menuturkan keinginan KH. Affan kepada Bapak Miska (salah satu hartawan di Krai)., akhirnya bapak Miskapun berkeinginan untuk mewaqafkan sebidang tanahnya untuk di bangun pesantren. Sekitar tahun 1982 beberapa tokoh masyarakat Desa Krai, yaitu Kiai Ahmad Tajuddin, KH. Hmid, H. Abd.Latif dan Bapak Miska sowan (menghadap) kepada KH. Abdullah yaqien dan KH. Affan Abd Malik untuk menuturkan tanah yang akan diwaqafkan dan meminta restu perihal pembangunan pesantren tersebut. Dan beliaupun merestui tentang pewaqafan tanah dan pembangunan pesantren tersebut.

Begitu besar keilkalasan dan ketabahan beliau KH. Affan Abd. Malik, meskipun hanya berbekal ilmu Allah dan dua pasang helai baju, beliau terus tekun membangun pesantren di bumi Krai. Dengan membabat kebun kelapa. Pembangunan masjid dimulai, KH. Affan Abd. Malik terus mengawasi pembangunan masjid tersebut dan wira-wiri dari pesantren Mlokorejo. Kemudian KH. Affan membentuk panitia pembangunan pesantren dan melakukan pembangunan masjid. Sebelum panitia terbentuk H.Hamid mulai meminta bantuan kepada beberapa masyarakat Krai dan dibentuklah panitia pembangunan pesantren yang diketuai oleh KH. Ali Murtadlo (tokoh massyarakat Krai), selaku pencari material bangunan seperti bambu, kayu, semen dan dana dimotori oleh Kiai Fathor Rozi (tokoh masyarakat). Terdapat juga beberapa santri dan alumni pesantren Mlokorejo dan kembang kuning yang masuk dalam kepanittiaan. Adapun keseluruhan jumlah dari panitia pada saat itu sebanyak 75.

Keiklasan dan ketekunan para panitia terlihat dari peristiwa tersebut layaknya heroik yang tak kenal menyerah dan terus berjuang. Para panitia mulai mencari sumbangan berupa kayu, bambu, batu bata, dana dan lain sebagainya. Hingga akhirnya 
beberapa truk berdatangan dengan membawa material-material yang akan digunakan untuk pembangunan masjid.

Tak semuda seperti yang dikira, Allah selalu menguji kesabaran hambahamba Nya. Berselang beberapa hari setelah kedatangan material tersebut.

Banyak material yang dicuri diantaranya 10 bal semen dan beberapa besi cor banyak yamg hilang. Mulai saat kejadian tersebut setiap panitia dibebani tugas piket jaga malam. Pembangunan pun dimulai dengan beberapa tukang dan bantuan dari para santri yang dibawah dari PP Bustanul Ulum Krai Mlokorejo dan PP Kembang Kuning Larangan Madura serta masyarakat sekitar.

KH. Abdullah Yaqien tidak serta merta melepas menantunya untuk berjuang sendiri di tempat hijra. Terkadang beliau berkunjung ke lokasi pembangunan untuk ikut mengawasi. Ketika beliau berkunjung banyak keluh kesah para panitia yang dituturkan pada beliau, tidak terkecuali kejadian na'as tersebut.

Seorang panitia pun menjawab "bedeh ka'disak kyaeh asmanah Bunaden" (ada kiai disana namanya bunaden), bunaden yang merupakan orang yang ditakuti para preman dan maling yang terkenal, dan memintanya untuk menghadap KH. Abdullah Yaqien.

Sesampainya di kediaman pengasuh pesantren Mlokorejo, beliau menuturkan maksud dan tujuan beliau memanggil Bunaden, yaitu hanya ingin menitipkan dan menjaga material di daerah pembangunan agar tidak kemalimgan lagi. Bunaden pun menyetujui permintaan dari $\mathrm{KH}$. Abdullah Yaqien begitu besar dan tersembuinyi kebesaran Allah, tanpa di duga beberapa waktu beerselang ketika Bunaden sering berjaga. Bunaden mulai berikrar dan berjanji akan bertaubat dasn ikut berjuang di jalan Allah dan alhamdulillah stelah itu materialmaterial tidak pernah kemalingan lagi. Kemudian Pak Miska membuat tenda yang dikhususkan untuk menjaga keamanan material, hingga pak Miska membawa peralatan dapur dan perlengkapan memasak sekedar untuk membuat kopi dan teh.

Sekitar tahun 1984 KH. Affan Abd Malik bersama keluarga mulai menetap pasti ditanah pesantren. Pada saat itu, telah terbangun masjid, Mushalla Putri, 3 asrama Putra, 1 Asrama Putri dan juga kediaman KH. Affan Abd Malik. Pondok peantren Bustanul Ulum Krai saat ini telah berkembang pesat dari awal yang hanya memiliki fasilitas lengkap berupaya asrama, gedung sekolah, laboratorium, lapangan olaraga, mushalah dan lain sebagainya. Fasilitas tersebut tidak serta merta datang begitu saja, banyak perjuangan yang dilalui Almagfurlah dan apara santri, dari awal berdirinya pesantren yang hanya di sinari terang lilin, kemudian mulai ada mesin Desel sekitar tahun 1990an. Hingga aliran listrik masuk dengan pasti menyinari tanah perjuangan para pahlawan dan pejuang islam di bumi hijau Bustanul Ulum Krai Krai.

Pada awalnya, santri Bustanul Ulum Krai merupakan PP. Kembang Kuning Madura dan PP.Bustanul Ulum Krai Jember yang berjumlah belasan gingga saat ini jumlah santri bermukim memiliki kurang lebih 500 orang dan lebih dari 100 santri tidak mukim yang bersekolah dinaungan Yayasan Pendidikan Islam Bustanul Ulum Krai, Madin (madrsah Diniyah) Bustanul Ulum Krai awaliyah dan wustho, santri sorogan, RA (Raudhatul Atfal) Bustanul Ulum Krai, MA (madrasah alityah) Bustanul Ulum Krai, Sekolah tinggi Islam Bustanul Ulum Krai.

Akses jalan yang mudah dan jenjang pendidikan yang lengkap dari RA sampai dengan perguruan Tinggi dari 
TPA hingga madrassah diniyah menjadikan Pondok Pesantren Bustanul Ulum Krai Krai menjadi pesantren yang maju dan sangat berkembang. Jejak perjuangan $\mathrm{KH}$. Affan Abd. Malik selaku pendiri dan pengasuh serta beberapa bantuan Kiai Mloko dan Madura, masyarakat, para santri senior dan para panitia sangat membekas. Semoga perjuangan beliau semua di terima oleh Allah dan kita sebagai santri Bustanul Ulum Krai dan mengikuti jejak perjuangan dan meneruskan perjuangan mereka. ${ }^{22}$

\section{Transformasi Kepemimpinan Pondok Pesantren Bustanul Ulum Krai Lumajang}

Mengenai perubahan pola kepemimpinan di pondok pesantren Bustanul Ulum Krai, Gus Naufal, salah satu putra pendiri pesantren mengatakan:

"Pondok pesantren ini didirikan pada tahun 1980, saya ditinggal Abah selaku Pendiri dan pengasuh pada waktu itu saya masih proses kuliah di Malang sehingga Kepemimpinan pada waktu itu diturunkan pada kakak saya. Namun akhirnya dibentuk yayasan dan melakukan perubahan pola kepemimpinan. Kami memulai membentuk biro pendidikan ini menangani seluruh tingkatan pendidikan yang ada dibawah naungan yayasan pondok pesantren mulai RA, MI, MTS, MA, S-1 STAIBU, ada juga biro kepesantrenan yang menangani Ma'hadiah atau progam-progam santri, peraturan-peraturan kepesantrenan lalu yang terahir biro keuangan." 23

Lebih lanjut, ia menuturkan bahwa perubahan pola kepemimpinan juga

${ }^{22}$ Abdul Mughits Naufal, Wawancara, 17 Maret 2019

23 Abdul Mughits Naufal, Wawancara, 17 bagian dari amanah pendiri. Mengenai hal ini, ia menuturkan:

\begin{abstract}
"Pengelolaan kepemimpinan dengan terbagi menjadi biro-biro ini atau yang disebut kolektif kolegial ini mempermudah podok pesantren dalam menjaga para santri dan meningkatkan kecerdasan para santri baik kecerdasan spiritual, intelektual, sebenarnya kepemimpinan pondok pesantren yang seperti ini sudah amanah dari abah sebelum wafat abah berkata ayo pondok pesantren iki dikroyok-kroyok sehingga munculah perubahan pola kepemimpinan kolektif kolegial. Dalam proses ini kebetulan saudara-saudara saya ini terlibat semua. Otomatis itu menjadi kekuatan bagi pondok pesantren karena sama sekali tidak mengurangi kewibawaan dan marwah karena yang berada di posisi puncak ini ya saudarasaudara saya ini kalau pun ada ustadz, alumni dan simpastisan itu tidak berada di posisi puncak mereka ada di posisi garis bukan di top leadhernya karna top leadhernya masih keluarga sendiri secara bersama-sama. ${ }^{24}$
\end{abstract}

Hal yang sama disampaikan ketua Pengurus Pondok Pesantren Bustanul Ulum Krai, Ustadzah Laila. Ia menyampaikan:

"Untuk di pondok pesatren Bustanul Ulum Krai sendiri baru mengalami perubahan pola kepemimpinan dimana kepemimpinan kiai terbagi menjadi tiga biro yang dibawah pimpinan utama yakni Ny. Hj azimah abdullah sebagai pengasuh utama, $\mathrm{KH}$. Raden Samhan Baqis Muhtadi pengasuh satu, KH. Ali Murtadlo Affan pengasuh dua, KH. Dimas Abdul Adim Affan pengasuh ke tiga serta Gus Abdul

${ }^{24}$ Abdul Mughits Naufal, Wawancara, 17 Maret 2019

Maret 2019 
Mugist Naufal Affan, S.Sy sebagai pengasuh ke empat"25

Senada dengan pernyataan di atas, ustadz. Hasyim asy'ari, sebagai wakil pengurus pondok menuturkan:

"Pondok pesantren Bustanul Ulum Krai dikelola secara bersama-sama oleh keempat pengasuh semua bekerja sesuai tugas dan wewenang bagian ma'hadiyah bertugas memantau mengarahkan segala perkara santri terkait dengan ubudiyah, akhlak masalah kepulangan dan kembalinya santri saat hari besar Islam yang sudah di tentukan jadwal pulangan yang di atur oleh pengasuh utama dan pengasuh pertama, untuk masalah adminitrasi surat-surat dan sebagainya yang sejenis di pantau oleh pengasuh yang ke dua, untuk masalah pengelolaan keuangan pondok pesantren di kelola oleh pengasuh ke tiga dan pengasuh keempat bertugas memantau masalah pendidikan baik lembaga formal pesantren atau di dalam kepesantrenan itu sendiri selain itu untuk model kepemimpinan yang dilakukan para pengasuh adalah mengembangkan pola kepemimpinan dengan kecakapan teknis, serta kepemimpinan demokratis yang tidak memberi jarak antara santri dan kyai begitu pula dengan masyarakat dan kyai". 26

Dapat disimpulkan bahwa kepemimpinan di Pondok Pesantren Bustanul Ulum Krai berbentuk kepemimpinan kolektif kolegial. Dimana pondok pesantren diasuh bersama-sama dan berbentuk bidangbidang. Pengasuh utama Ny. Hj azimah Abdullah sebagai penasehat dari permasalahan yang ada, Pengasuh 1, KH. Raden Samhan Baqis Muhtadi

25 Laila, Wawancara, 18 Maret 2019.

${ }^{26}$ Hasyim asy'ari, wawancara, Lumajang, sebagai biro Ma'hadiyah yang bertugas terkait kepesantrenan. Pengasuh 2, KH. Ali Murtadlo Affan sebagai biro adminitrasi yang bertanggung jawab dengan segala administrasi pondok pesantren. Pengasuh 3, KH. Dimas Abdul Adim Affan sebagai biro keuangan dan pengasuh 4 , Gus Abdul Mugist Naufal Affan, S.Sy sebagai biro pendidikan yang dilakukan paska wafatnya pendiri pondok Bustanul Ulum Krai yaitu K.H. Affan abdul malik tepatnya pada tahun 2009.

Penuturan yang sama disampaikan $\mathrm{Bu}$ Indah, salah satu wali santri. Berkenaan dengan kepemimpinan kolektif kolegial, ia menyampaikan:

\begin{abstract}
"Dulu kalau mau ngijinkan pulang dan mau mengurusi pembayaran ataupun minta nasehat kami datang hanya ke K.H. Raden Samhan Baqis Muhtadi, namun sekarang kami bisa menemui pengasuh-pengasuh yang berbeda sesuai dengan keperluan kami dan itu lebih membantu kami karena tidak terpacu dengan satu kiai saja."27
\end{abstract}

Perubahan yang dilakukan tentu mengalami dampak yang tidak sederhana. Menenai hal tersebut, Gus Naufal menyampaikan bahwa perubahan kepemimpinan yang baru berdampak pada perubahan sistem juga. Secara tidak langsung, pesantren dituntut untuk selalu melakukan musyawarah dalam menentukan putusan dan kebijakan-kebijakan baru sebagai konsekwensi perubahan pola tersebut.

Keadaan yang dialami Bustanul Ulum Krai ini membenarkan pendapat Gus Dur dan Nurcholis Madjid sebagaimana pada penjelasan sebelumnya. Dua hal yang diusulkan

\footnotetext{
27 Indah, Wawancara, 17 Maret 2019
} 17 Maret 2019. 
yakni modernisasi dan yayasan, keduanya sama-sama diterapkan di pesantren ini. Dengan model kepemimpinan kolektif, akhirnya pesantren bisa menjadi lembaga modern yang kelangsungannya tidak tergantung oleh seorang kiai sebagai pemimpin tertinggi lagi tunggal. Upaya menerapkan model kepemimpinan kolektif dalam meenejemen pesantren merupakan suatu ikhtiar pembinaan pesantren sekaligus salah satu jawaban dari problem kepemimpinan tersebut. Senada dengan itu, Mujamil Qomar juga mengatakan bahwa perubahan kepemimpinan mampu menyuguhkan kerangka teoritis dan filosofis bagi pendidikan yang relevan dengan kebutuhan bangsa di masa depan. ${ }^{28}$

\section{Kesimpulan}

Pondok Pesantren merupakan salah satu elemen penyelenggara pendidikan islam yang telah mengambil peran dalam pengembangkan SDM walaupu setelah merdeka telah berkembang lembaga pendidikan formal namun keberadaan pesantren belum mampu digeser oleh lembaga pendidikan Islam formal tersebut. ciri umum pesantren yang tersebar luas di Indonesia mengandung unsur unsur: (1) Kiai sebagai pendiri, pelaksana dan guru; (2) Pelajar (santri) yang secara pribadi langsung diajar berdasarkan naskahnaskah arab klasik tentang pengajaran faham dan akidah ke islaman. pesantren sebagai institusi pendidikan Islam baik dalam sistim pondok tradisional maupun modern juga sebagai usaha Pendidikan ummat Islam. Karena pesantren juga berfungsi sebagai pusat pengembangan masyarakat. pesantren dalam kegiatan kegiatan proses belajar dan mengajar kewirausahaan dan pertanian serta kegiatan ekstra kurikulernya melibatkan masyarakat sekitarnya.

Bentuk tranformasi kepemimpinan dalam menjawab tantangan globalisasi di Pondok Pesantren Bustanul Ulum Krai Lumajang tahun 2019 adalah dengan melakukan perubahan pola kepemimpinan tunggal menjadi kolektif kolegial. Pengelolaan pembelajaran dan administrasi juga mengalami pembaharuan dengan inovasi yang diciptakan oleh pengurus pondok pesantren. Implikasinya, transformasi kepemimpinan dapat berdampak positif bagi para santri dan pondok pesantren terutama dalam menjawab kebutuhan global.

\section{Referensi}

Arifin, Imron, Penelitian Kualitatif dalam Ilmu-Ilmu Social dan Keagamaan, Malang: Kalimasahada Press, 1996

Bogdan, Robert C. and Sari Knopp Biklen, Qualitative Research for Education: An Introduction to Theory and Methods, London: Allyn and Bacon Inc, 1992

Chotib, Moch, Pesantren dan Masyarakat Transformatif. Jember: Pena Salsabila, 2010

Dhofier, Zamakhsyari, Tradisi Pesantren: Studi Tentang Pandangan Hidup Kiai. Jakarta: LP3ES, 1982

Hamdan, Farchan dan Syarifuddin, Titik Tengkar Pesantren: Resolusi Konflik Masyarakat Pesantren, Yogyakarta: Pilar Religia, 2005

\footnotetext{
28Muzamil Qomar, Transformsi Kepemimpinan Pesantren, 51.
} 
In'am, Sulaiman, Masa Depan Pesantren: Eksistensi Pesantren di Tengah Gelombang Modernisasi. Malang: Madani, 2010

Madjid, Nurcholish. Bilik-Bilik Pesantren, Sebuah Potret Perjalanan. Jakarta: Paramadina, 1992

Miles, Metthew B., A. Michael Huberman and Johnny Saldana, Qualitative Data Analysis, A Methods Sourcebook, Sage Publications, Inc., 2014

Muhadjir, Noeng, Metodologi Penelitian Kualitatif, Yogyakarta: Rake Sarasin, 1993

Muttaqin, Ahmad Ihwanul. "Dinamika Islam Moderat, Studi atas Peran LP. Ma'arif NU Lumajang dalam Mengatasi Gerakan Radikal," Tabiyatuna: Jurnal Pendidikan Islam. Vol. 12, No. 1 (2019)

Nasir, M. Ridwan. Format Pendidikan Ideal Pondok Pesantren Tengah Arus Perubahan. Yogyakarta: Pustaka Pelajar, 2010

Nasution, Metode Penelitian Naturalistik Kualitatif, Bandung: Tarsito, 2003

Qomar, Mujamil, Pesantren dari Transformasi Metodologi Menuju Demokrasi Institusi. Jakarta: Erlangga, 2002

Suriana, "Pendidikan Islam Di Era Globalisasi: Menggapai Peluang, Menuai Tantangan", Jurnal Mudarisuna, Vol 4, No 2 (2014)

Wahid, Abdurrahman. Menggerakkan Tradisi. Yogyakarta: LKiS, 2011

Yasmadi. Modernisasi Pendidikan Islam. Ciputat: Ciputat Press, 2002

Yin, Robert K., Studi Kasus Desain dan Methode, Jakarta: PT. Raja Grafindo Persada, 2002 